\title{
Organic Consumer Segmentation
}

\author{
Javier de Esteban Curiel ${ }^{1 *}$, Juan Carlos Castro², Mauricio Quisimalín² \\ ${ }^{1}$ Department of Marketing, Rey Juan Carlos University, Madrid, Spain \\ ${ }^{2}$ Department of Economics and Business, Technical University of Ambato, Ambato, Ecuador \\ Email: ${ }^{*}$ javier.deesteban@urjc.es
}

Received 9 March 2015; accepted 13 July 2015; published 16 July 2015

Copyright (C) 2015 by authors and Scientific Research Publishing Inc.

This work is licensed under the Creative Commons Attribution International License (CC BY).

http://creativecommons.org/licenses/by/4.0/

(c) (i) Open Access

\begin{abstract}
One of the aspects that configure the social agreement these days in Ecuador is based on the "Food Sovereignty". In this sense, this paper tries to identify and validate determinant factors over the consumption of ecological food in Ecuador. Among other factors, the authors analyse the demographic characteristics, the knowledge about organic agriculture, the attitudes towards environmental issues, the considerations about organic product sales, the lifestyles and the main priorities when choosing food. The population of study was the city of Ambato, province of Tungurahua (Ecuador) with a sample size of 400 subjects in order to determine the patterns of organic consumption right there. In particular, this research was conducted through a face-to-face survey of 40 questions considering 86 variables divided into blocks of perceptions, attitudes, behaviours and socio-demographic profiles, such as income source, home size, education level, lifestyle or monthly family incomes. Hence, a model of analysis is determined on the awareness of organic products and its association with ecological purchase.
\end{abstract}

\section{Keywords}

Segmentation, Segmentation Criteria, Ecological Consumer

\section{Introduction}

The World Bank in its report on agriculture development envisioned a food crisis by increasing the prices of agricultural products (Waldman, Sumner, \& Leach, 2008) and manufacture products on a large scale. This action will make an increasing scarce of the planet's resources for most people in the world, running businesses with a lack of consideration to the environment in their managerial issues (Santos Soret, 2002) adding up another problem that affects the supply of the population, as well as the survival of millions of peasants in the world (Leff, 2008) causing the stagnation of demand and market saturation (Sanchez, Gil, \& Grace, 2000).

${ }^{*}$ Corresponding author. 
Consumption increases low prospects selfish values (health, food safety, physical characteristics of the products) and altruistic aspects (environment, animal welfare, territorial development). Under this scenario, a critical exposure of factors by the consumer perception of organic food (Vega Parras, Murgado, \& Ruiz, 2013) is seen as a new alternative, safe, clean and ethical consumption (Griffith \& Zepeda, 2003) displaying the ecological decision as a complex competitive business scenario. In this sense, food companies seek the connection between environmental protection and gaining competitive advantages (Weatherell, Tregear, \& Allinson, 2003) to be represented in a change of organizational vision (Plaza Úbeda, Burgos Jimenez Ureña, \& Belmonte, 2011).

Ecuador could not stay behind in the organic market with a growing concern of food security (Sanchez, Sanjuan, Roig, Gracia, \& Soler, 2011) institutionalized in 1) the Constitution of Ecuador, National Plan for Good Living 2013-2017, in the National Objectives founded mainly on shafts 2) rights, freedoms and capabilities to the Good Life; and 3) economic-productive from the change of the productive matrix, this has caused Transformation Organic Food justify an appropriate policy of differentiation, which is becoming a strategic necessity to survive in the Ecuadorian market according to the National Planning Council 2009.

People are demanding what they consume, triggering concern for food consumption, health, environmental degradation (Mollá-Bauza \& Vilas, 2001) as well as an improvement of the management practices and technologies in agriculture (Anderson, Wachenheim, \& Lesch, 2007). These issues justify the rise of organic food consumption in developed countries especially the United States, Western Europe and Japan, which are also major importers of organic food (Griffith \& Zepeda, 2003). This new kind of food respecting the environment pursues to meet the new demands of responsible consumption (Medium \& Vincent, 2002) or ethical consumption (Dueñas Ocampo, Perdomo-Ortiz, Villa, \& Brown, 2014).

Under this reasonable and timely juncture it is imperative for companies to regulate themselves under the perspective of responsible management setting policies, objectives, strategies and generating administrative procedures that respect the environment (Plaza Ubeda et al., 2011), allowing supply products less contaminated, and adapting the marketing mix variables of this ecological niche to an unbalanced management philosophy of responsible marketing (Salinas \& Andrés, 2004).

Having a lack of background in this country in general and in the city of Ambato in particular, this study might be considered unique and original, with an exploratory and descriptive analysis of the outlook of Ambato. In fact, there is a need to widen and make more effective the segmentation of this type of ecological marketstrategy which allows identifying the profile of the so-called ecological consumer. Most results of the very few previous studies of this type of consumer have been incomplete. For example the one conducted by Ortiz \& Flores (2008) only considers traditional segmentation variables. Therefore, this paper extends and specifies the profile of the consumer under the view of psychographic and behavioral variables which define the profile of the consumer in a more efficient way. Even, it could be helpful in the future to design the marketing strategies for this type of segments in Ecuadorian companies.

In this scenario mentioned above, the primary flashpoint was based on determining the market segment for organic food, low demographic, lifestyle, environmental preferences, and economic, psychographic and behavioral variables characterizing the classic and non-classic segmentation.

As noted earlier, in Ecuador there are few studies on organic market segmentation, so this study could draw attention on international research as "strategic segmentation of the ecological market" (Vicente \& Mediano, 2002), especially where there is high environmental awareness on new food businesses (Vega et al., 2013). Indeed the term organic plays an important role with heuristic superiority (Salinas \& Andrés, 2004) for companies that design their business strategies toward green lifestyles of consumers that are eager to try new things and experience new challenges.

Within this context, some hypotheses have been proposed for the theoretical implications of this study that can sustain a practical overview marketing strategy. In particular, these hypotheses are based on the behavioral preferences, lifestyles and environmental concerns of Ambato residents interested in the organic food market in Ecuador.

One of the main marketing segmentation strategy has been stated by David (2003) claiming for an effective market analysis and a heterogeneous universe divided into groups according to some specific characteristics (Schiffman \& Kanuk, 2005; Vicente \& Mediano, 2002). On the other hand, Fernández (2001) ratifies "the division of a heterogeneous universe into groups with at least one homogeneous feature" in order to polish much better marketing strategies. Thus, consumer segments are reduced and companies must struggle to capture the most attractive segments (Lamb, Hair, \& Daniel, 2006: p. 224) with the implementation of "ad hoc" loyalty 
programmes.

Santesmases (2004: p. 212 cited by Gutierrez, 2008: p. 48) indicates that marketing segmentation is a process of dividing the market into subgroups as homogeneous as possible so that companies could accomplish and meet their needs more effectively. Therefore, it is imperative that each of the segments has different marketing strategies to bring new customers to the companies and grow their brand (Sierra, 2005).

It is noted that buyers differ in one or more issues when deciding on the purchase of a good or service (Kotler \& Armstrong, 2003) with differences on their desires, resources, locations, buying attitudes, practice purchases, etc. However for Malhotra, Martínez, \& Rosales (2004) the initiative of dividing a market into distinct subsets of consumers and selecting one or more segments is intended to get through a specific marketing mix in order to respond accurately to the needs of buyers (Schiffman \& Kanuk, 2005).

One of the problems facing the majority of Ecuadorian companies goes through the precarious market segmentation that does not cater effectively the needs of buyers (Corner, 2008). To increase sales and utilities becomes a normal scenario where customer's non-loyalty is set up. Hence, companies seek to satisfy their customers by implementing more accurate marketing actions that consider the differences among individuals (Díaz \& Rubio, 2006; Schiffman \& Kanuk, 2005). Therefore, the “market segmentation” becomes a need of urgency in order to divide prospect buyers into different groups (Kotler \& Armstrong, 2003; Kotler, 2003; Malhotra et al., 2004; Schiffman \& Kanuk, 2005). The outcomes of this process are the market segments with relatively homogeneous characteristics that must be figure out by companies.

Reading this context, companies have moved from a "Mass Marketing” to a “One-to-One Marketing” (Kotler, 2003) where the products accomplished better the needs of different segments in terms of features, benefits, etc. In words of Professor Lambin (1995), differentiation is a concept that lies in the diversity of the supply with two levels: 1) among competitors of the same product type, and 2) among the products of one single manufacturer. This occurs if a product is launched for different segments, requiring a differentiation in the sense that buyers perceive different solutions to several problems at the same time (Ruiz, 2001).

With regard to the "ecological segmentation", new segmentation alternatives have favoured organic foods to define new marketing possibilities and new purchasing attempts (Mollá-Bauza \& Vilas, 2001; Torjusen, Lieblein, Wandel, \& Francis, 2001). This type of market has currently great potential for growth and development in Ecuador, considering factors such as environmental awareness, concerns about health issues and culture of responsible consumption, among others (Sánchez et al., 2011).

However, this attractive outcome under the perception of organic food (Roitner-Schobesberger Darnhofer, Somsook, \& Vogl, 2008) is only possible when the process of segmentation and marketing actions allow efficiently to meet this type of market (i.e. the investment is made to be rebounded in sales so that the company increases its sales revenue, profit and return on investment). Therefore, with the idea of reaching what was previously described, this research work analyses the development of the primary objective based on determining the segment of ecological products under certain demographic, economic, psychographic and behavioral criteria. Consequently, some marketing segmentation variables have been crossed with some sociodemographic variables (related with the lifestyle and environmental preferences) in order to obtain the focal point of this paper.

\section{Methodology}

There are very few investigations on this topic in Ecuador in general and particularly in Ambato. This study has an exploratory and descriptive character. Generally in this research was used bivariate data analysis. The main idea was to find out the relationships between the following variables in the city of Ambato: perception of organic food of the potential consumers, demographic characteristics of the respondents; knowledge of respondents on organic agriculture; attitudes towards environmental issues; organic food in grocery shops; factors which are leading to the food choices, etc.

In this research project for the first stage there was used probability cluster sampling technique. There were chosen different geographic clusters in the city of Ambato. On the second stage there was applied simply random technique in order to obtain primary data on the research topic. The sampling size for this investigation was 400 (15 years old and order). There have been used a confidence level $95 \%$ and a sampling error of 5\% over the universe of all inhabitants the city of Ambato. For the survey data collection the researchers used personalized face-to-face interviews which lasted approximately 15 minutes per person. The basis of the research construct instrument was obtained through the secondary academic literature. Also the secondary data literature allowed 
exploring different definitions on the research topic. This kind of literature exploration has permitted to adapt this research to a particular case: the city of Ambato. Here we would like to mention some experts on our research topic who have been used for the bases of the construct: Camino, 2001; Chamorro, Miranda, \& Rubio, 2006; Gordillo Delgado, Zárate Rincón, \& Mejia Morales, 2012; Ortiz \& Miguel Flores, 2008; Roitner-Schobesberger et al, 2008.

For a questionnaire validity, there have been used a pre-test. In the pre-test $10 \%$ of the elements from the total sampling size have participated (e.g. 40 individuals in total). These individuals were chosen on the same basis as general sampling elements of the city of Ambato. There have been applied personal face-to-face interviews during the questionnaire layout pre-test. 10 of 40 selected individuals refused to participate in this research pre-pest. The applied pre-test permitted to validate previously created questionnaire questions and variables.

The final questionnaire layout of this survey consisted of 40 open-ended and closed-ended questions, and 86 variables. In the closed-ended questions there were given, nominal, ordinal and scale-based alternatives. All the 40 questions were divided in three thematic blocks.

Once the fieldwork was finished and before the univariate and bivariate analysis of the primary data, the authors of this research have calculated the Cronbach Alpha index in order to obtain internal consistency of the chosen instruments for the survey technique. Hence, for this study the Cronbach Alpha value was 0.83 which indicates, on basis of other this kind of academic researches, that there is good internal consistency of the chosen instruments. In this sense, with this significant Cronbach Alpha index, the authors have continued with bivariate statistical analysis of results. The bivariate analysis was treated with statistical software IBM SPSS 22.

\section{Results}

After analyzing the data it is stated that there is a significant portion of the sample subjects, they had never heard about organic food. In this context the first step was to compare the demographic profiles of different organic consumer segments (Table 1 ).

Continuing with Table 1, the analysis of independence between variables was carried out based on some demographic variables (such as, main household incomes, household size, education level, monthly family incomes) which interpretation as a whole can be reasonably significant (for the association of variables, authors have used the Chi-square coefficient). Indeed, if association is significant it means that, at certain levels of the independent variables, the concentration of responses is greater or less than expected by chance (homogenous responses). As it can be seen, the dependent variable "Organic buyers" (with 67.3\%) is significantly associated with the variable "Main source of household incomes". Furthermore, those who work as employees tend to buy more ecological goods than self-employees. Households with a size of 3 - 4 family members tend to buy green at $65.1 \%$ of its total. On the other hand, the concept "organic buyers" with $64.5 \%$ is also significantly associated with the "educational level" (in particular, the highest educational level). Those with higher levels of education tend to buy organic more often than those with lower levels. Besides, families with mid-household incomes per month (ranging from $\$ 501$ - \$1000) tend to buy organic more often.

Table 2 shows the level of ecological knowledge of those who have heard about organic and its association with "organic non-buyers" and "organic buyers" (again Chi-square coefficient analysis). The first variable indicates the opinion about the ecological knowledge (level of knowledge regarding organic farming): $85.7 \%$ of organic buyers have a "very good" ecological knowledge. The second variable describes and explores the concept of organic food where $81.8 \%$ of the organic buyers have actually knowledge of the variable "processed without chemicals". The third variable reveals that organic farming is good for the environment: in particular, $86.6 \%$ of the organic buyers agree with this statement. In fact, it has been founded a highly association between those thinking "organic farming is good for the environment" and those declared "organic buyers" (it exist a significance level of influence). The fourth variable indicates about the time of existence of organic farms: $79.3 \%$ of organic buyers consider this phenomenon relatively from few years ago, the same as $30.3 \%$ who have heard about organic. Then, a significant association exists between the operationalized concepts of "time of existence of organic farms" and "organic buyers".

Meanwhile, Figure 1 shows the food buying process according to the lifestyle, attitudes to environmental issues and the place of purchase for "organic buyers" versus "non-organic" (ordinal variables from 1-low to 5-high have been considered as well as a nonparametric test of Kruskal-Wallis). As a result, green consumers (aka "organic-buyers) give much importance to some variables, such as "good for health", "environmentally 
Table 1. Demographic characteristics of respondents. Source: authors.

\begin{tabular}{|c|c|c|c|c|c|}
\hline Variable & $\begin{array}{l}\text { Number of } \\
\text { respondents }\end{array}$ & $\begin{array}{l}\text { Never-heard } \\
\text { organic }\end{array}$ & $\begin{array}{c}\text { Organic } \\
\text { non-buyers }\end{array}$ & $\begin{array}{l}\text { Organic } \\
\text { buyers }\end{array}$ & $\begin{array}{l}\text { Significance of the } \\
\text { difference between } \\
\text { the groups }{ }^{\mathrm{b}}\end{array}$ \\
\hline Age & & & & & ns \\
\hline$<25$ years & 205 & $36.6 \%$ & $12.2 \%$ & $51.2 \%$ & \\
\hline 26 - 35 years & 87 & $24.1 \%$ & $12.6 \%$ & $63.2 \%$ & \\
\hline 36 - 45 years & 61 & $29.5 \%$ & $13.1 \%$ & $57.4 \%$ & \\
\hline$>46$ years & 47 & $31.9 \%$ & $8.5 \%$ & $59.6 \%$ & \\
\hline Sex & & & & & ns \\
\hline Male & 174 & $34.5 \%$ & $9.7 \%$ & $55.7 \%$ & \\
\hline Female & 226 & $30.5 \%$ & $13.7 \%$ & $55.7 \%$ & \\
\hline $\begin{array}{l}\text { Main source of household } \\
\text { incomes }\end{array}$ & & & & & * \\
\hline Self-employed & 111 & $36.0 \%$ & $13.5 \%$ & $50.4 \%$ & \\
\hline Employee & 107 & $22.4 \%$ & $10.3 \%$ & $67.3 \%$ & \\
\hline Others & 182 & $35.7 \%$ & $12.1 \%$ & $52.2 \%$ & \\
\hline Household size & & & & & * \\
\hline$<2$ members & 29 & $37.9 \%$ & $6.9 \%$ & $55.2 \%$ & \\
\hline 3 - 4 members & 215 & $26.0 \%$ & $8.8 \%$ & $65.1 \%$ & \\
\hline$>5$ members & 156 & $39.7 \%$ & $17.3 \%$ & $42.9 \%$ & \\
\hline Educational level & & & & & $*$ \\
\hline Primary school & 34 & $44.1 \%$ & $11.8 \%$ & $44.1 \%$ & \\
\hline Secondary school & 140 & $32.9 \%$ & $14.3 \%$ & $52.9 \%$ & \\
\hline University & 195 & $31.3 \%$ & $10.3 \%$ & $58.5 \%$ & \\
\hline MSc or higher & 31 & $22.6 \%$ & $12.9 \%$ & $64.5 \%$ & \\
\hline Family incomes per month & & & & & * \\
\hline$<250 \$$ & 37 & $46.0 \%$ & $13.5 \%$ & $40.5 \%$ & \\
\hline $251 \$-500 \$$ & 87 & $33.3 \%$ & $6.9 \%$ & $59.8 \%$ & \\
\hline $501 \$-1000 \$$ & 168 & $26.8 \%$ & $9.5 \%$ & $63.7 \%$ & \\
\hline $1001 \$-1500 \$$ & 74 & $35.1 \%$ & $23.0 \%$ & $41.9 \%$ & \\
\hline$>1501 \$$ & 34 & $35.3 \%$ & $11.8 \%$ & $52.9 \%$ & \\
\hline
\end{tabular}

${ }^{\mathrm{a}}$ Some information was missing on some questionnaires, thus not all categories add up 400 respondents. ${ }^{\mathrm{b}}$ Significance ${ }^{*}=<0.05$; ns: not significant.

friendly", "easily available”, "special offers" and "well-known brand name”, when they choose foods in the shopping process.

Finally, the authors have carried out a diagram tree analysis of the dimensions "household size" and "lifestyle" regarding the price of organic food consumption. A diagram tree represents graphically and analytically events that arise from a decision made at a point in time and it allows better decisions from a probabilistic point of view and a list of possible choices. Diagram trees allow to examine visually the results and determine the consistency of the model. Visual results help to find specific subgroups and relationships that may not be able so obvious with descriptive statistics. Furthermore diagram trees serve as a statistical technique for segmentation, stratification, prediction, data reduction, variable screening, identification of interactions, category merging and discretizing continuous variables which imply to identify groups, discover relationships between them and predict future events. 
Table 2. Knowledge about organic farming by the respondents who have hear of "organic" in percent. Source: authors.

\begin{tabular}{|c|c|c|c|c|}
\hline Variable & $\begin{array}{l}\text { Have heard } \\
\text { "organic" }\end{array}$ & $\begin{array}{c}\text { Organic } \\
\text { non-buyers }\end{array}$ & $\begin{array}{c}\text { Organic } \\
\text { buyers }\end{array}$ & $\begin{array}{l}\text { Significance of the } \\
\text { difference between } \\
\text { the groups }^{\mathrm{a}}\end{array}$ \\
\hline What is your level of knowledge about organic farming? & & & & ns \\
\hline Very little & $9.2 \%$ & $32.0 \%$ & $68.0 \%$ & \\
\hline Little & $10.3 \%$ & $14.3 \%$ & $85.7 \%$ & \\
\hline Ordinary & $28.4 \%$ & $20.8 \%$ & $79.2 \%$ & \\
\hline Good & $31.4 \%$ & $14.1 \%$ & $85.9 \%$ & \\
\hline Very good & $20.7 \%$ & $14.3 \%$ & $85.7 \%$ & \\
\hline What do you understand by organic foods? & & & & ns \\
\hline Are those sold directly from the farm & $16.3 \%$ & $11.4 \%$ & $88.6 \%$ & \\
\hline Are produced without using chemicals & $50.9 \%$ & $18.1 \%$ & $81.9 \%$ & \\
\hline Are processed without using chemicals & $28.4 \%$ & $18.2 \%$ & $81.8 \%$ & \\
\hline Are whole foods & $4.4 \%$ & $33.3 \%$ & $66.7 \%$ & \\
\hline Organic farming is good for the environment & & & & * \\
\hline Yes, I agree & $77.1 \%$ & $13.4 \%$ & $86.6 \%$ & \\
\hline No, I do not think so & $7.4 \%$ & $20.0 \%$ & $80.0 \%$ & \\
\hline I do not know & $15.5 \%$ & $38.1 \%$ & $61.9 \%$ & \\
\hline Organic farming has existed since... & & & & * \\
\hline Always existed & $50.2 \%$ & $11.8 \%$ & $88.3 \%$ & \\
\hline Few months & $19.6 \%$ & $28.3 \%$ & $71.7 \%$ & \\
\hline Few years & $30.3 \%$ & $20.7 \%$ & $79.3 \%$ & \\
\hline
\end{tabular}

${ }^{\text {a Significance }}{ }^{*}=<0.05$; ns: not significant.

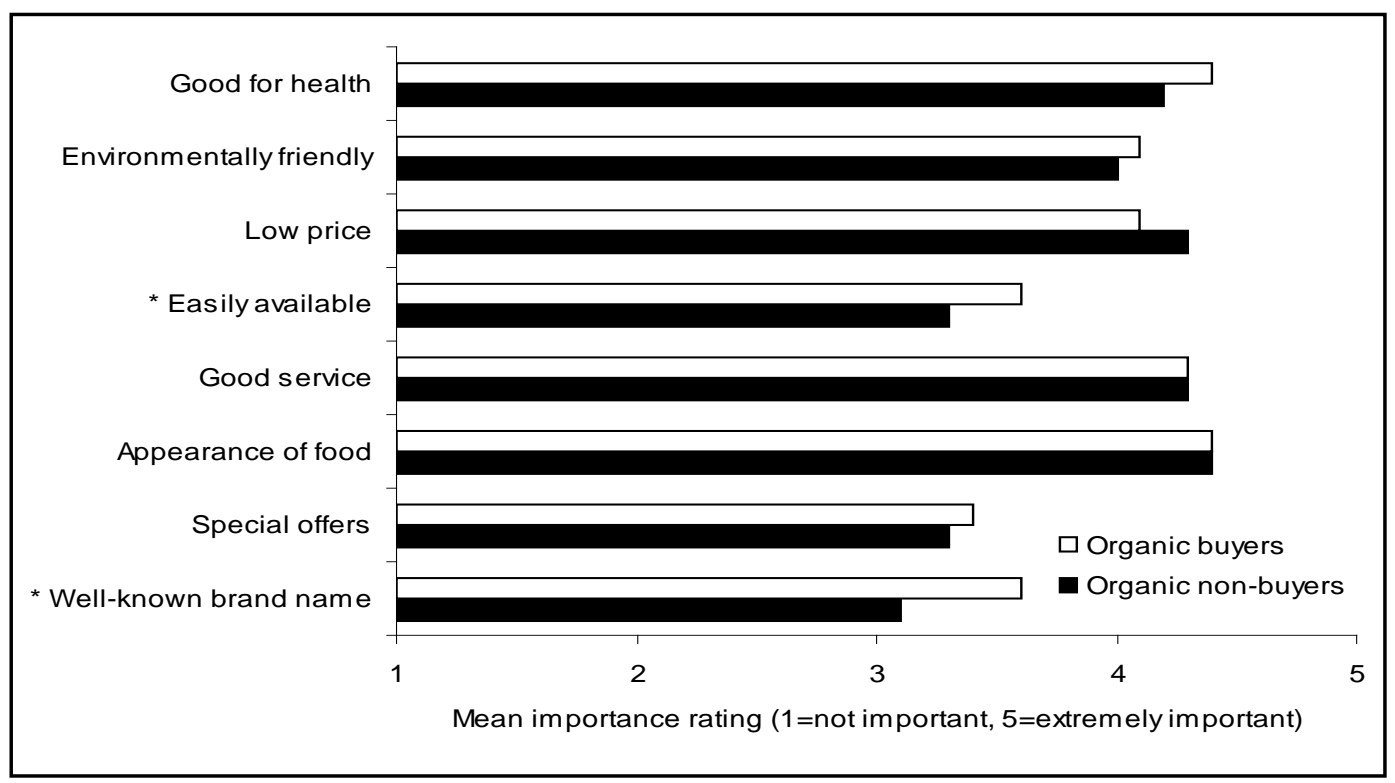

Figure 1. Importance of food choice issues, by organic non-buyers and organic buyers respondents (significance ${ }^{*}=<0.05$ ). 
For an explanation of the dimension "household size” (see Figure 2) Node 0 describes the dependent variable, that is, the "perception of potential consumers on the price of organic food". Then we note that the dependent variable is branched out into two nodes (Node 1 and Node 2) belonging both to the variable "importance of price when buying food" that acts as the main predictor.

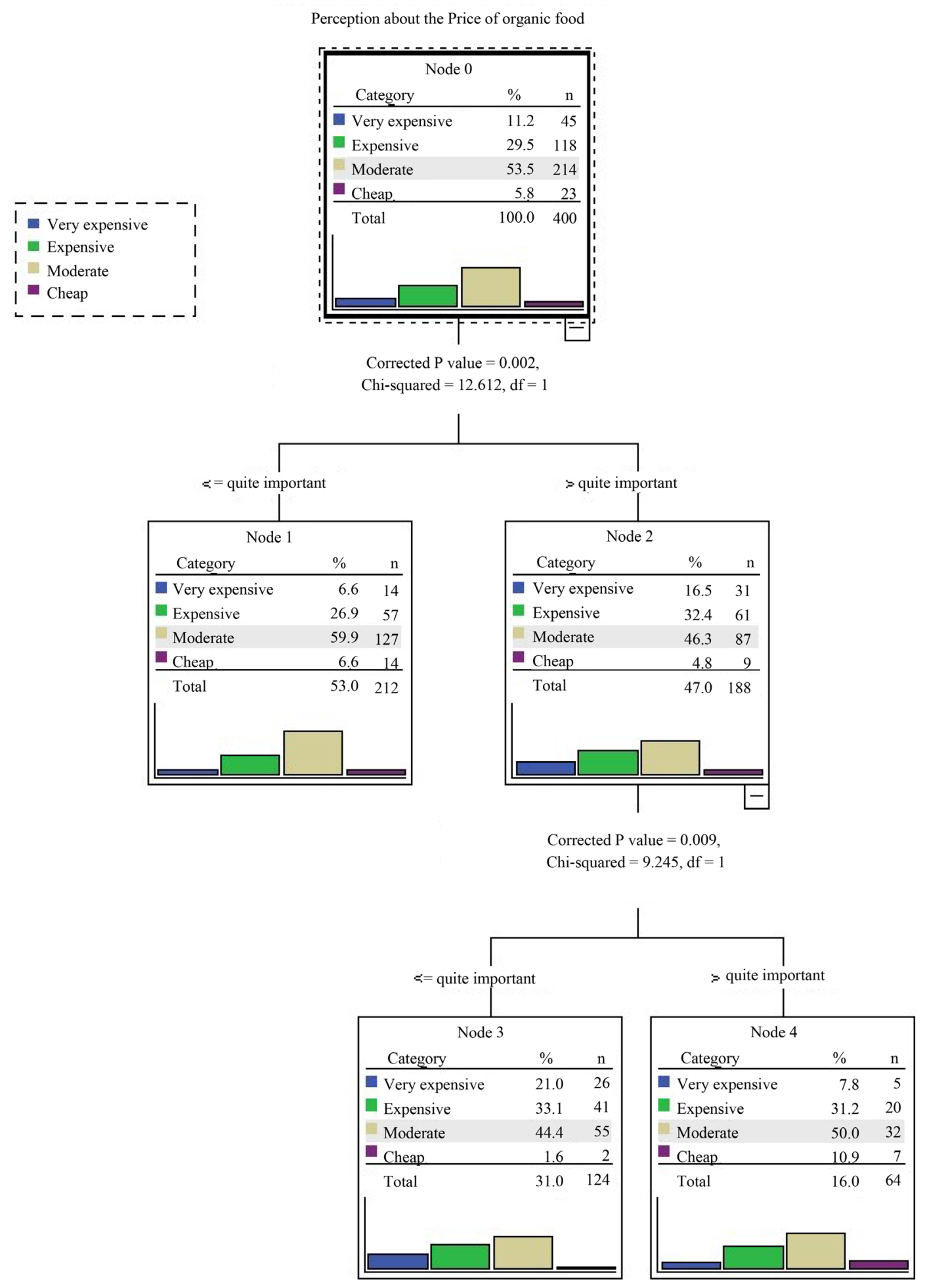

Figure 2. Diagram tree to model the household size on consumption of organic food. Source: Authors. 
As shown in Node 0, the Chi-Square is greater than Node 2, and Node 1 indicates that those who do not really consider price as an important factor when buying organic food, just $59.9 \%$ underline that the prices are moderates.

From its part, Node 2 splits into the Node 3 and Node 4 determining the importance of the brand when buying a particular food product. In this sense, Node 4 shows that half of the consumers (50\%), who believe the brand is pretty important, feel prices as moderates when buying organic food. Conversely, just 44, 4\% of Node 3 (e.g. subjects that consider not really consider important the brand) score prices as moderates.

In a nutshell, the Nodes that define the profile of potential consumers in the perception of the price of organic food (variables that influence price) are Node 0, Node 1 and Node 4 (in other words, the "price" and the "brand"). The highest probability of price perception (50\%) occurs among respondents who believe that the brand is very important when buying organic food; the lowest probability when they do not give relevance to the brand.

The prediction model appears in the following table of "risk and classification", providing a quick assessment of how it fits from a methodological point of view (Table 3):

This table shows that the model correctness classifies around $53.5 \%$ of the respondents in general and provides the highest achievements in the case of the "moderate" category (with 100\%).

With regard to the "lifestyle" dimension (see Figure 3), Node 0 describes the dependent variable, that is, the percentage of those who are willing to eat organic food. Then, the dependent variable is branched out into two nodes: Node 1 and Node 2 where the variable is exposed to the control (or not) of salt intake, the main predictor variable.

According to this figure, Node 1 has a Chi-Square coefficient slightly higher than Node 2. Nevertheless, Node 2 indicates that the vast majority (85.7\%) of those seeking to control salt intake in organic foods, are eager to consume organic food.

Node 2 turns into Node 5 and Node 6 considering the variable "medical checkups". Thus, Node 5 highlights that the subjects willing to eat organic food if medical checkup is performed stand for $90.5 \%$, whereas $79.6 \%$ Node 6 if non-medical checks.

In summary, the Nodes that define the profile of those who are willing to consume organic foods are: Node 0Node 1-Node 2-Node 5 and Node 6. In other words: salt intake and medical checkups. Finally, the prediction model variables appear in the table of "risk and classification", providing a quick assessment of how it fits from a methodological point of view (Table 4):

This table shows that the model correctness classifies around $79 \%$ of the respondents in general and provides the highest achievements in the case of the "would consume" category (with 100\%).

Table 3. Risk and classification tables of the decision tree. Source: Authors.

(a)

\begin{tabular}{ccc}
\hline Method & Estimation & Standard error \\
\hline Resubstitution & 0.465 & 0.025 \\
Cross-validation & 0.482 & 0.025 \\
\hline
\end{tabular}

Growing method: CHAID; dependent variable: Perception about the price of organic food.

(b)

\begin{tabular}{|c|c|c|c|c|c|}
\hline \multirow{2}{*}{ Observed } & \multicolumn{5}{|c|}{ Predicted } \\
\hline & Very expensive & Expensive & Moderate & Cheap & Percent correct \\
\hline Very expensive & 0 & 0 & 45 & 0 & $0.0 \%$ \\
\hline Expensive & 0 & 0 & 118 & 0 & $0.0 \%$ \\
\hline Moderate & 0 & 0 & 214 & 0 & $100.0 \%$ \\
\hline Cheap & 0 & 0 & 23 & 0 & $0.0 \%$ \\
\hline Overall percentage & $0.0 \%$ & $0.0 \%$ & $100.0 \%$ & $0.0 \%$ & $53.5 \%$ \\
\hline
\end{tabular}

Growing method: CHAID; dependent variable: Perception about the price of organic food. 
Table 4. Tables risk classification decision tree. Source: authors.

(a)

\begin{tabular}{ccc} 
Method & Estimation & Standard error \\
\hline Resubstitution & 0.210 & 0.020 \\
Cross-validation & 0.210 & 0.020 \\
\hline
\end{tabular}

Growing method: CHAID; dependent variable: Perception about the price of organic food.

(b)

\begin{tabular}{ccccc}
\hline Observed & \multicolumn{3}{c}{ Predicted } \\
\cline { 2 - 5 } & Would consume & Would not consume & Depends & Percent correct \\
\hline Would consume & 316 & 0 & 0 & $100.0 \%$ \\
Would not consume & 31 & 0 & 0 & $0.0 \%$ \\
Depends & 53 & 0 & 0 & $0.0 \%$ \\
Overall percentage & $100.0 \%$ & $0.0 \%$ & $0.0 \%$ & $79.0 \%$ \\
\hline
\end{tabular}

Growing method: CHAID; dependent variable: Perception about the price of organic food.

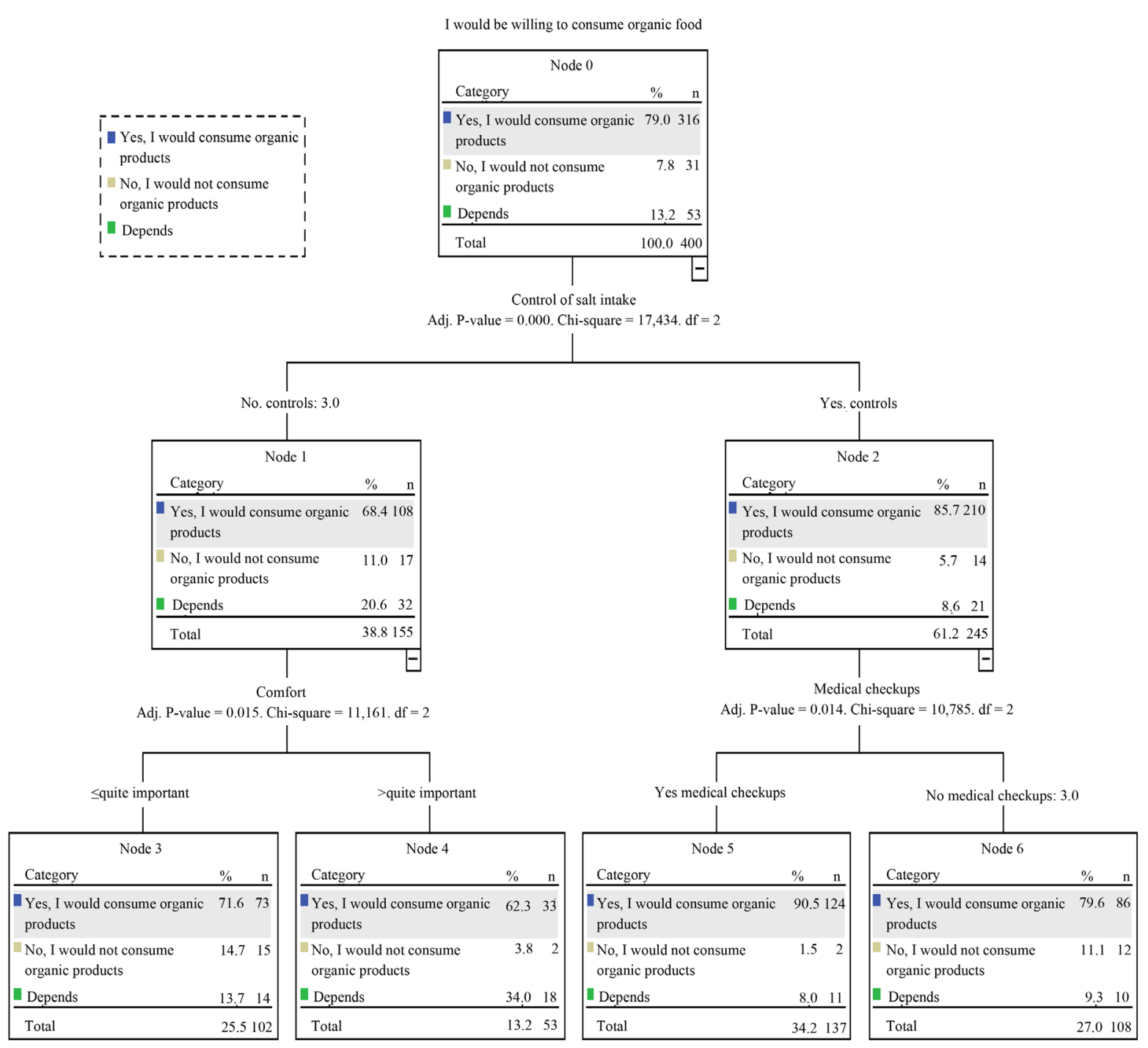

Figure 3. Diagram tree to model the lifestyle dimension about eating organic foods. Source: authors. 


\section{Further Results Discussion}

The financial crisis all around the world has modified the idea of ecological purchases. With this crises also have appeared a critical thinking of what we eat, is it healthy and how does it influence our environment. These issues also have affected the cost and profitability of the global market. The main results of this research work show that ecologic food purchases in Ecuador mainly are made by families that consist of $3-4$ people, they have a university degree and they belong to a middle class. Furthermore, the interviewed people made their product purchases on basis of their level of knowledge on eco-products and they associate it as something opposite to the processed and with the food chemicals full products. Hence, on the basis of the obtained data, it reveals that ecological goods come from organic agriculture and are considered as something good for environment. With these previously mentioned statements and based on the research findings, we can see that it is not enough for the ecological purchases to have only traditional segmentation variables, as have suggested Ortiz and Flores (2008), because it makes research less important by leading only to the demographic aspects, and also study could be unproductive on a certain level which complicates moment of the strategic decision-making process.

Our needs, wishes and the market demands make us think of positive attitudes towards our health and how we care about it. Under this perspective, the purchase habits established by the ecological consumer could be considered as that: this kind of food is good for our health and it doesn't damage our natural ecosystem. These findings also confirm what have remarked by Vicente and Mediano (2002) that the environmental conscience and new demands for the companies is a strategic axis which plays an important role and is a heuristic signal to superiority. This research results also reveals the idea which was written by Salinas and Andrés (2004) that companies need to bear in mind, for a design of their commercial communication strategies, that nowadays many consumers like to practice ecological lifestyles, try new things, face new challenges and exigencies which are based on accessibility of the products that are offered by well-known labels and are available in a market at a reasonable price.

Finally, the ecological food consumers affirm that a price at the moment of a purchase is extremely important. Therefore, it means that this kind of consumer is very sensible to the price and its changes. In this sense, a node, which defines a profile of possible consumer and his price perception of the eco-product, refers to the label. Moreover, the price aspect in a moment of purchase is the best predictor of a price perception when consumers decide to buy a food for their meals at home. It is also important to mention that a lifestyle which is based on an extreme care of health (e.g. no use of salt in a food), regular medical checkups and other activities, ratify what have said Vega, Parras, Murgado and Ruiz (2013) that consumption increases under a perspective of selfish values (health, food security, physical characteristics of the products) and altruist ones (environmental, animal welfare, territory development). Hence, it is essential to understand that for the ecological food product consumers the main perception factors for consumption is security, cleanness and ethical issues.

\section{Conclusions and Implications}

This empirical research is the first study in the city of Ambato which demonstrates a potential green thinking and green acting consumer. The first step of this investigation was to compare profiles of consumers on basis of the traditional demographic variables like gender, age, household income and size, educational level and etc. Also there have been used questions related to knowledge and purchase of an organic food.

For better clarification and interest to define more precise ecological food product consumer, there have been studied issues related to his/her knowledge on the eco-products and willingness to buy them. Therefore, this research also was highlighting the idea of how have changed the consumer views on environmental matters during the last years in Ecuador.

Finally, this research project has studied some buying and consumption habits in the city of Ambato. However, the results show that there are some differences between the consumers "wishes and companies" supply on the ecological food products. It means that there is not enough supply of eco-products in Ecuador and there is more demand than offer.

At this moment, it can be observed that an organic agriculture is more concentrated for the international market and not for the domestic one. Thus, lately the Government of Ecuador tries to improve a national public policy for the foods' security and hopes for a significant growth of the organic foods' production for the local marketplace. This, previously mentioned tendency is completely opposite what we can see in Europe (e.g. the Netherlands, Norway, Spain, France and Germany) and the United States of America, where the local markets are 
full with the ecological food products and totally replies to the demands of their consumers.

After all this, the new demand for an organic food is creating a new model of consumption and agricultural production in Ecuador. Therefore, we would like to mention that we can start to see some slight movements of the ecological food producers in the city of Ambato, for example, a "Pacat Ambato" organization which consists of small scale producers. Also this organization uses agro marketing approaches for the commercial communication strategies. But we have to remind that there are very few studies on this topic and particularly on the segments of the ecological food consumers in Ambato. Hence, this investigation provides a first level knowledge on this topic and reflections of various stakeholders involved in an organic farming.

This study also allows determining the knowledge and potential consumption habits of the potential purchasers which can occur by appearing of the organic products and agro-ecological farming. The results show that people who have heard something about organic food products, later on they have more interest in consuming them. From this point of view, we can affirm that there is a gap of information on the benefits of the organic food in Ecuador.

In summation, this investigation displays evidences on the individuals' preferences in Ecuador regarding their present and future purchases of the eco-products. This study could help to build better profiles of this kind of consumers and to provide improved understanding of the present urgent market in Ecuador.

\section{References}

Camino, J. R. (2001). El marketing medioambiental en España. Esic Market, 63-76.

Chamorro, A., Miranda, F., \& Rubio, S. (2006). El estado de la investigación sobre el marketing ecológico en España. Investigaciones Europeas de Dirección y Economía de la Empresa, 12, 137-156.

David, F. R. (2003). Conceptos de administración estratégica. Madrid: Pearson Educación.

Díaz, A. B. C., \& Rubio, R. S. (2006). Dirección de Marketing: Teoría y Práctica. Editorial Club Universitario.

Dueñas Ocampo, S., Perdomo-Ortiz, J., \& Villa Castaño, L. E. (2014). El concepto de consumo socialmente responsable y su medición. Una revisión de la literatura. Estudios Gerenciales, 30, 287-300. http://dx.doi.org/10.1016/j.estger.2014.01.022

Gordillo Delgado, F., Zárate Rincón, F., \& Mejía Morales, C. (2012). Comparison between Convenional and Organic Rice Using Photoacoustics Technique. DYNA, 79, 7-13.

Griffith, G. R., \& Zepeda, L. (2003). An Overview of the Organic Food Products Market in Australia by Hui-Shung (Christie) Chang. Armidale, N.S.W.: University of New England, Graduate School of Agricultural and Resource Economics.

Kotler, P. (2003). Direccion de Marketing: Conceptos Esenciales. Madrid: Pearson Educación.

Kotler, P., \& Armstrong, G. (2003). Fundamentos de Marketing. Madrid: Pearson Educación.

Lambin, J. J. (1995). Marketing Etratégico (3rd ed.). España: McGraw-Hill.

Leff, E. (2008). Decrecimiento o desconstrucción de la economía: Hacia un mundo sustentable. Polis (Santiago), 7, 81-90. http://dx.doi.org/10.4067/S0718-65682008000200005

Malhotra, N. K., Martínez, J. F. J. D., \& Rosales, M. E. T. (2004). Investigación de mercados. México: Pearson Educación.

Mollá-Bauza, M. M. B., \& Vilas, L. M. R. (2001). Comportamiento del consumidor valenciano ante los productos ecológi cos e integrados. Revista Española de Estudios Agrosociales y Pesqueros, 105-122.

Ortiz, D. A., \& Flores, M. (2008). Consumo de productos orgánicos/agroecológicos en los hogares ecuatorianos. http://www.siicex.gob.pe/siicex/documentosportal/alertas/documento/doc/63780450radBF21D.pdf

Plaza Úbeda, J. A., de Burgos Jiménez, J., \& Belmonte Ureña, L. J. (2011). Grupos de interés, gestión ambiental y resultado empresarial: Una propuesta integradora. Cuadernos de Economía y Dirección de la Empresa, 14, 151-161. http://dx.doi.org/10.1016/j.cede.2011.02.001

Roitner-Schobesberger, B., Darnhofer, I., Somsook, S., \& Vogl, C. R. (2008). Consumer Perceptions of Organic Foods in Bangkok, Thailand. Food Policy, 33, 112-121. http://dx.doi.org/10.1016/j.foodpol.2007.09.004

Ruiz, B. L. P. (2001). La Esencia Del Marketing. Barcelona: Universitat Politècnica de Catalunya.

Salinas, E. M., \& Andrés, E. F. (2004). El consumo ecológico explicado a través de los valores y estilos de vida: Implicaciones en la estrategia medioambiental de la empresa. Cuadernos de Ciencias Económicas y Empresariales, 33-53.

Sánchez, M., Sanjuán, A. I., Roig, J. M. G., Gracia, A., \& Soler, F. (2011). Estudio de las preferencias de consumidores y distribuidores especializados respecto del producto ecológico. Economía Agraria y Recursos Naturales (Agricultural and Resource Economics), 2, 93-114.

Schiffman, L. G., \& Kanuk, L. L. (2005). Comportamiento del consumidor. México: Pearson Educación.

Sierra, J. A. (2005). Marketing para editoriales universitarias en el siglo XXI. Jorge Alfonso Sierra Quinte. 
Torjusen, H., Lieblein, G., Wandel, M., \& Francis, C. A. (2001). Food System Orientation and Quality Perception among Consumers and Producers of Organic Food in Hedmark County, Norway. Food Quality and Preference, 12, 207-216. http://dx.doi.org/10.1016/S0950-3293(00)00047-1

Vega, M., Parras, M., Murgado, E., \& Ruiz, J. (2013). The Influence of the Term “Organic” on Organic Food Purchasing Behavior. Procedia-Social and Behavioral Sciences, 81, 660-671. http://dx.doi.org/10.1016/j.sbspro.2013.06.493

Vicente, M. A., \& Mediano, L. (2002). Propuestas para una segmentación estratégica del mercado ecológico. https://addi.ehu.es/handle/10810/6999

Waldman, L., Sumner, A., \& Leach, M. (2008). Technology, Rural Dynamics and Pro-Poor Development. The European Journal of Development Research, 20, 371-376. http://dx.doi.org/10.1080/09578810802273560

Weatherell, C., Tregear, A., \& Allinson, J. (2003). In Search of the Concerned Consumer: UK Public Perceptions of Food, Farming and Buying Local. Journal of Rural Studies, 19, 233-244. http://dx.doi.org/10.1016/S0743-0167(02)00083-9 